\title{
Catalytic Reduction of Calcium Sulfate to Calcium Sulfide by Carbon Monoxide
}

\author{
Hongjian Li and Yahui Zhuang* \\ Research Center for Eco-E nvironmental Sciences, Chinese Academy of Sciences, P.O. Box 2871, \\ Beijing 100085, China
}

\begin{abstract}
The catalytic reduction of calcium sulfate to calcium sulfide by carbon monoxide over various catalysts was investigated. An optimum conversion rate of more than $95 \%$ was obtained at 660 ${ }^{\circ} \mathrm{C}$ over a $\mathrm{Ni}-\mathrm{Fe}$ mixed catalyst. Parametric studies on the performance of the catalyst have been conducted. The parameters studied include temperature, composition of catalysts, concentration of catalysts, reaction time, and CO concentration. Some physicochemical characteristics of samples were studied by using X-ray diffraction (XRD), scanning el ectron microscopy (SEM) and Brunauer-Emmett-Teller (BET) measurements, and a possible mechanism is proposed.
\end{abstract}

\section{Introduction}

Calcium sulfate is one of the most widespread natural sulfates and the main byproduct of phosphoric acid plants, flue gas desulfurization units, and thermal power units. It represents a tremendously large potential source of sulfur.1,2 Many processes have been devel oped to recover chemical values such as sulfur or sulfuric acid from calcium sulfate. Current commercial methods for manufacturing sulfur from calcium sulfate are through (1) the reduction of calcium sulfate to calcium sulfide and (2) the conversion of cal cium sulfide to sulfur ${ }^{3-6}$ Many reducing agents, such as coal, coke, $\mathrm{CH}_{4}, \mathrm{CO}$, and $\mathrm{H}_{2}$, can be used to reduce calcium sulfate to calcium sulfide, but temperatures over $850{ }^{\circ} \mathrm{C}$ are required to obtain near-stoi chi ometric conversions. ${ }^{3,7-9}$ Kale et al. studied the effect of various catalysts impregnated in the matrix of carbon and discovered that mixed catalysts such as potassium dichromate can enhance the reaction rate quite satisfactorily and the reaction can take place at $740-860{ }^{\circ} \mathrm{C} .{ }^{10}$ Ragin and Brooks studied phosphogypsum reduction to calcium sulfide and discovered that phosphogypsum can be reduced to calcium sulfide at $850-1000{ }^{\circ} \mathrm{C}$ by using either coal or $\mathrm{CO}$ as a reductant and the required temperature can be lowered to $750{ }^{\circ} \mathrm{C}$ with $\mathrm{Fe}_{2} \mathrm{O}_{3}$ and so on as catalysts. ${ }^{11}$ Trikkel and K uusik also discovered that some additives, especially a semicoke of coal that contain $>20 \%$ volatiles in dry matter in a mixture with ferric oxide can intensify the calcium sulfide recovery process and raise the calcium sulfide yiel d. ${ }^{12}$ Zadick et al. found that ferric oxide, stannous sulfate and vanadium pentoxide have pronounced catalytic effect on the reduction of calcium sulfate. ${ }^{13}$ But even with the use of various catalysts, the temperatures required for the process of reducing calcium sulfate to calcium sulfide were still higher than the theoretical temperatures, especially for the following reaction:

$$
\mathrm{CaSO}_{4}(\mathrm{~s})+4 \mathrm{CO}(\mathrm{g})=\mathrm{CaS}(\mathrm{s})+4 \mathrm{CO}_{2}(\mathrm{~g})
$$

The reaction is thermodynamically feasible even at

* Corresponding author. Telephone: (+86) 1062923564. Fax: (+86) 10 62923563. E-mail: zhuangyh@sun.ihep.ac.cn. ambient temperatures, 9,14 and this fact inspired us to find an effective mixed catalyst that can promote the reduction reaction at lower temperatures.

\section{Experimental Section}

2.1. Materials. In this study, analytical grade dihydrated calcium sulfate (Beijing Chemical Reagent Corp., purity $99.0 \% \mathrm{CaSO}_{4} \cdot 2 \mathrm{H}_{2} \mathrm{O},<100$ mesh) was used for all runs. Analytical grade reagents, such as $\mathrm{Fe}\left(\mathrm{NO}_{3}\right)_{3}, \mathrm{CO}$ $\left(\mathrm{NO}_{3}\right)_{2}, \mathrm{Ni}\left(\mathrm{NO}_{3}\right)_{2}, \mathrm{Cu}\left(\mathrm{NO}_{3}\right)_{2}, \mathrm{~K}_{2} \mathrm{Cr}_{2} \mathrm{O}_{7}, \mathrm{Na}_{2} \mathrm{CO}_{3}$, and others, were used as catalyst precursors. Analytical grade CO (Beijing Industrial Gases Corp., 99.9\% CO) was used as the reducing gas. High-purity nitrogen $\left(99.99 \% \mathrm{~N}_{2}\right)$ was used as the inert component in the gas mixtures.

2.2. Sample Preparation. In the case of soluble catalyst precursors, samples were prepared by impregnating a certain amount of dihydrated calcium sulfate powder with an appropriate amount of aqueous solutions of single or mixed salts for $24 \mathrm{~h} .{ }^{10}$ Samples then were dried at $120^{\circ} \mathrm{C}$ for $2 \mathrm{~h}$, ignited at $600{ }^{\circ} \mathrm{C}$ under an atmosphere of high-purity nitrogen for $1 \mathrm{~h}$, and finally pulverized with a mortar and pestle. In the case of insoluble salts, samples were prepared by thoroughly mixing a certain amount of dihydrated calcium sulfate powder with an appropriate amount of catalyst precursors by using a mortar and pestle.

2.3. Experimental Procedure. Experiments were carried out under the atmospheric pressure in a fixedbed flow reactor $(25.0 \mathrm{~mm}$ inside diameter). For each run, about $500 \mathrm{mg}$ of a sample was used. The dried, cooled sample was weighed and placed in a quartz sample pan. The sample pan was placed inside the reactor by properly positioning the uniform hot zone of the furnace. During the preheating period, high-purity nitrogen was introduced to purge the system. After the system had reached a desired temperature, a reducing gas stream continuously passed through the reactor. The flow rate was $100 \mathrm{~mL} / \mathrm{min}$. After a desired period of time, the system was again purged with high-purity nitrogen until the sample cooled. Then the sample was wei ghed and analyzed for CaS by an iodi metric method. The conversion rate ( $R \%)$ of calcium sulfate to calcium sulfide was calculated by means of the following 


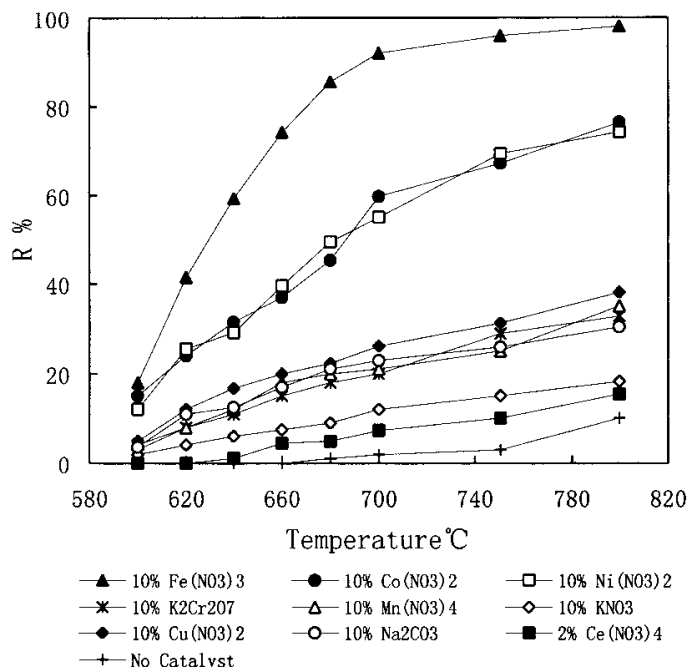

Figure 1. Conversion rates of various catalysts (reaction time $=$ $60 \mathrm{~min}$ and $\% \mathrm{CO}=30 \%$ ). The percentages of catalysts refer to mole percentiles of catalysts to calcium sulfate).

expression:

$$
\mathrm{R} \%=\left[\mathrm{N}_{\mathrm{CaS}}\right]_{\mathrm{p}} /\left[\mathrm{N}_{\mathrm{CaSO} 4}\right]_{\mathrm{f}} \times 100 \%
$$

In the expression, $\left[\mathrm{N}_{\mathrm{CaS}}\right]_{\mathrm{p}}$ and $\left[\mathrm{N}_{\mathrm{CaSO}}\right]_{\mathrm{f}}$ represent the moles of $\mathrm{CaS}$ in products and the moles of $\mathrm{CaSO}_{4}$ in feeds, respectively.

2.4. XRD Measurement. The composition of samples was determined by X-ray powder diffraction (XRD) techniques using a Siemens K500 diffractometer and copper $\mathrm{K} \alpha$ radiation over a $2 \theta$ range of $20-70^{\circ}$.

2.5. SE M Measurement. The morphol ogical changes of samples were examined by scanning electron microscopic (SEM) techniques using an AMRAY 1910 scanning electron microscope.

2.6. BET and Pore Volume Measurements. The BET surface area and pore volume of samples were measured using an ASAP 2000 analyzer with nitrogen as the analysis gas.

\section{Results and Discussions}

3.1. Activities of Various Catalysts. First, we studied the catalytic activities of various catalysts, and the results are shown in Figure 1, Figure 2 and Table 1 , respectively.

Figure 1 shows that the conversi on of calcium sulfate to calcium sulfide is a function of temperature for various catalysts. Apparently, ferric nitrate is the most active catalyst precursor among all tested catalysts. This result is consistent to the findings of other authors. ${ }^{11-13}$ Second to ferric nitrate, both nickel nitrate and cobalt nitrate show good catalytic activities.

Among the various iron precursor species, tervalent iron precursor gives the best catalyst, whereas the elemental iron precursor shows no catalytic activity.

Mixed $\mathrm{Ni}-\mathrm{Fe}$ and $\mathrm{Co}-\mathrm{Ni}$ salts gave strikingly high conversion of calcium sulfate. For both catalysts, the conversion rate reaches a maximum value when $\mathrm{M} / \mathrm{M}$ $+\mathrm{Fe})=1 / 3$. At this point, $\mathrm{Ni}-\mathrm{Fe}$ and $\mathrm{Co}-\mathrm{Fe}$ mixed oxides may form some stable chemical compounds. However, Cu-Fe and Zn-Fe mixed salts have no effect on the conversion of calcium sulfate. The conversion decreases with a decrease of the iron content.

3.2. Parametric Studies. The effect of temperature, catalyst concentration, reaction time, and the $\mathrm{CO}$ con-

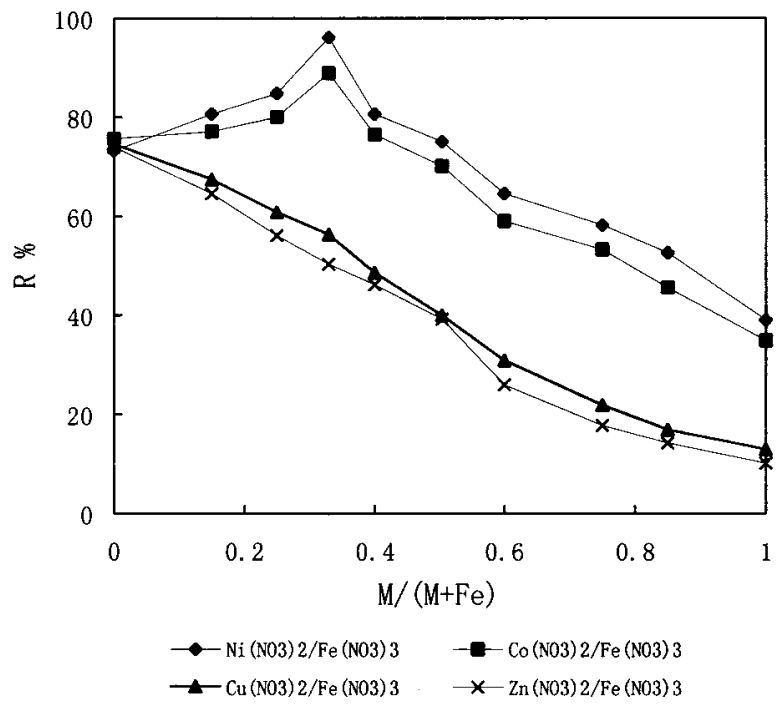

Figure 2. Effect of catalyst composition on the conversion rate $\left(\mathrm{T}=660{ }^{\circ} \mathrm{C}\right.$, reaction time $=60 \mathrm{~min}, \% \mathrm{CO}=30 \%$, and catalyst concentration $=10 \mathrm{~mol} \%)$.

Table 1. Catalytic Effect of Various Iron Precursor Species $^{\mathrm{a}}$

\begin{tabular}{cc}
\hline sample & $\mathrm{R} \%$ \\
\hline $10 \mathrm{~mol} \% \mathrm{Fe}_{\left(\mathrm{NO}_{3}\right)_{3}}$ & 72.2 \\
$10 \mathrm{~mol} \% \mathrm{Fe}_{2} \mathrm{O}_{3}$ & 68.5 \\
$10 \mathrm{~mol} \% \mathrm{Fe}_{3} \mathrm{O}_{4}$ & 38.3 \\
$10 \mathrm{~mol} \% \mathrm{Fe}\left(\mathrm{NO}_{3}\right)_{2}$ & 13.2 \\
$10 \mathrm{~mol} \% \mathrm{Fe}$ & 1.0 \\
$\mathrm{a} \mathrm{T}=660{ }^{\circ} \mathrm{C}$, reaction time $=60 \mathrm{~min}, \mathrm{CO} \%=30 \%$.
\end{tabular}

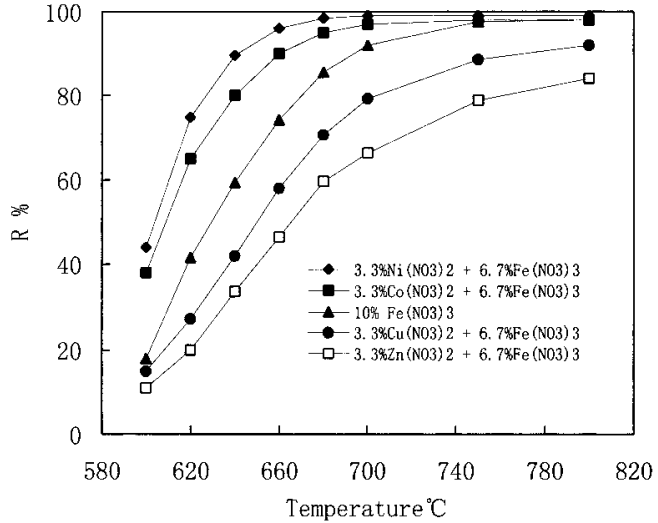

Figure 3. Effect of temperature on calcium sulfate conversion rate for different catalysts (reaction time $=60 \mathrm{~min}$ and $\% \mathrm{CO}=$ $30 \%)$.

centration on the conversion of the reduction of calcium sulfate to calcium sulfide were investigated.

From Figure 3, we can see that the $\mathrm{Ni}-\mathrm{Fe}$ and $\mathrm{Co}-$ Fe mixed salts are more active than the ferric salt at lower temperatures, whereas $\mathrm{Cu}-\mathrm{Fe}$ and $\mathrm{Zn}-\mathrm{Fe}$ mixed salts are less active than the ferric salt.

Figure 4 shows that the conversion rate at first increases with an increase of catalyst concentration. The conversion rate then remains stable, when the mole percent of the catalyst exceeds $8 \%$. For practical purposes, it is recommended to keep the concentration of the catalyst between $8 \%$ and $10 \%$.

The conversion rate is a function of time (Figure 5). For samples with $\mathrm{Ni}-\mathrm{Fe}$ mixed salt, reaction is al most completed after $45 \mathrm{~min}$, whereas for samples with ferric salt, the conversion rate still increases with time even after $60 \mathrm{~min}$. 


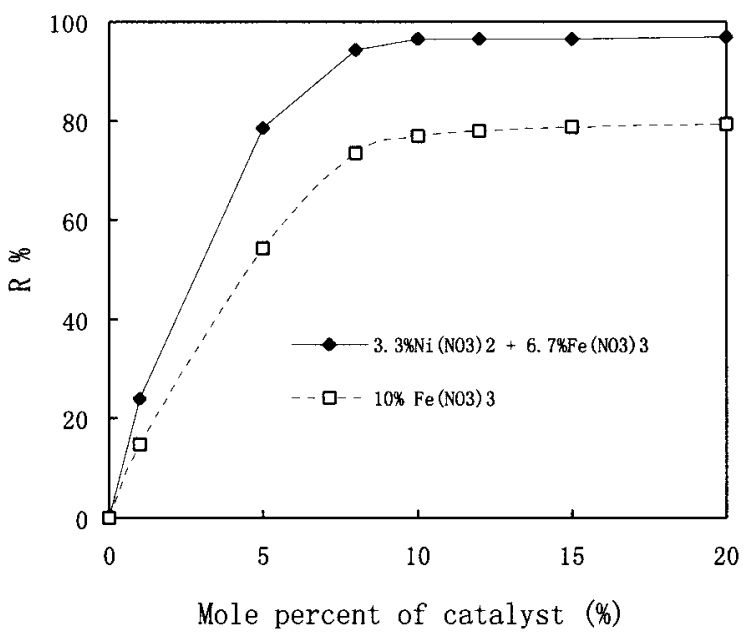

Figure 4. Effect of catalyst concentration on the conversion rate of calcium sulfate $\left(\mathrm{T}=660{ }^{\circ} \mathrm{C}\right.$, reaction time $=60 \mathrm{~min}, \% \mathrm{CO}=$ $30 \%$, and $\mathrm{Ni} /(\mathrm{Ni}+\mathrm{Fe})=1 / 3)$.

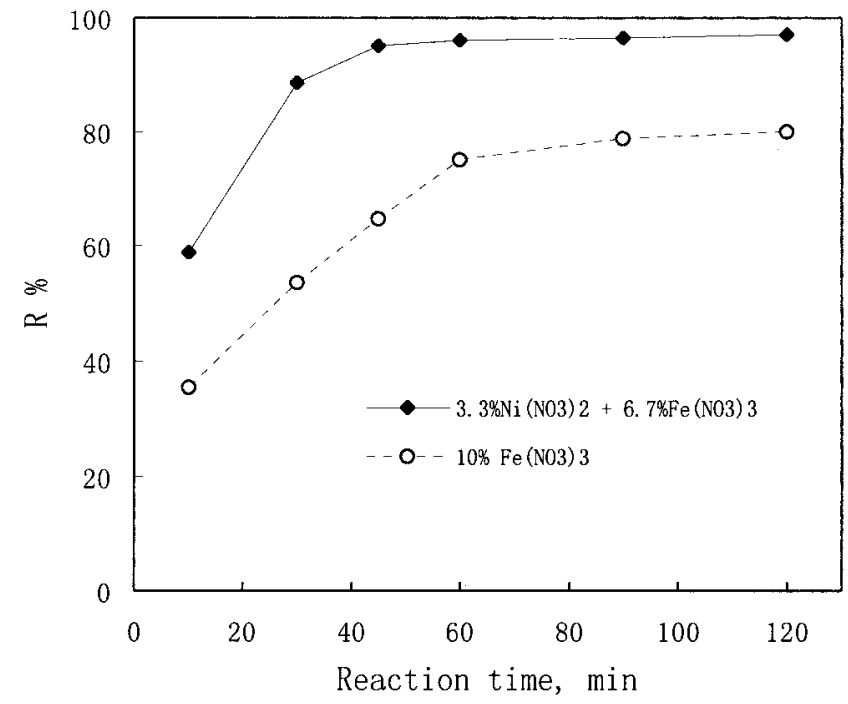

Figure 5. Relationship between the conversion rate and reaction time $\left(\mathrm{T}=660^{\circ} \mathrm{C}\right.$ and $\left.\% \mathrm{CO}=30 \%\right)$.

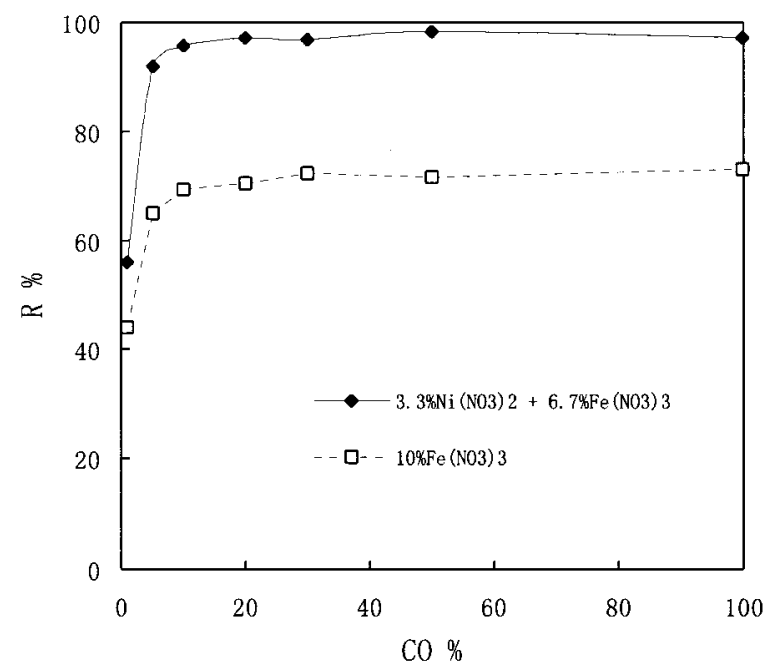

Figure 6. Effect of $\mathrm{CO}$ concentration on the conversion rate ( $\mathrm{T}=$ $660^{\circ} \mathrm{C}$ and reaction time $=60 \mathrm{~min}$ ).

Figure 6 shows that for both catalysts the CO concentration has a dramatic effect on the conversion rate, if CO concentration is less than $10 \%$. The conver-

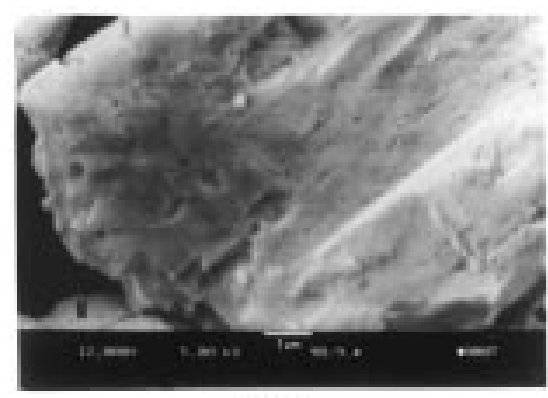

(a)

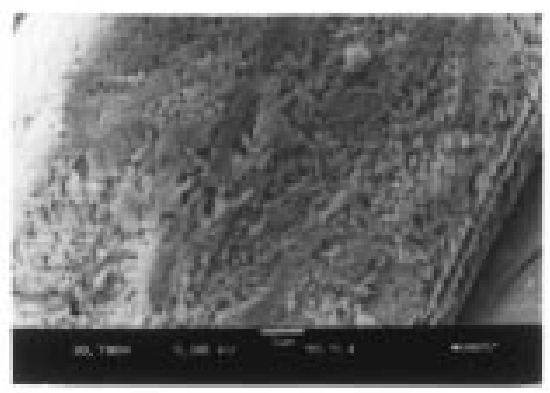

(b)

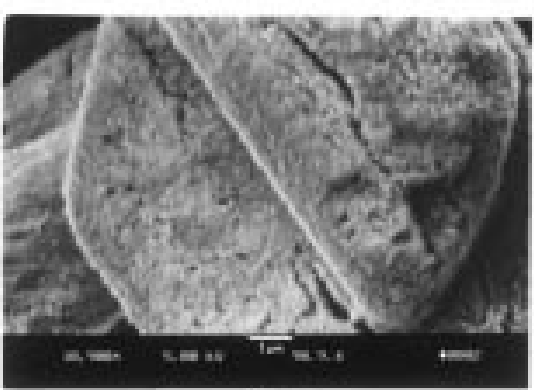

(c)

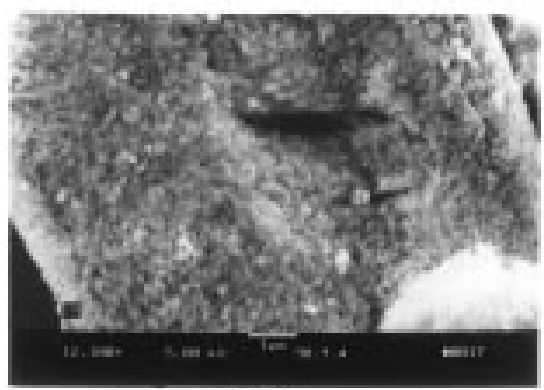

(d)

Figure 7. SEM micrographs of samples before and after reaction. (a) Sample prior to reduction with no metal salts added, $12000 \times$. (b) Sample prior to reduction with $10 \mathrm{~mol} \% \mathrm{Ni}-\mathrm{Fe}$ mixed salt $(\mathrm{Ni} / \mathrm{Fe}=1 / 2)$ added, $10700 \times$. (c) Sample from part a after reaction for $120 \mathrm{~min}$ at $800{ }^{\circ} \mathrm{C}, 10900 \times$. (d) Sample from part b after reaction for $30 \mathrm{~min}$ at $650^{\circ} \mathrm{C}, 12100 \times$.

sion rate then becomes stable, when $\mathrm{CO}$ concentration is higher than $10 \%$.

3.3. SEM, BET, and XRD Characterization. To study the morphological changes and the composition of samples, scanning electron microscopic, BET, and pore volume measurements, as well as X-ray diffraction measurements, were carried out. The results are shown in Figure 7, Table 2 and Figure 8, respectively.

From Figure 7, we can see that sample a has a dense morphological structure and sample b has highly dispersed metal salts on its surface. Evidently, sample b 
Table 2. BET and Pore Volume Measurements of Samples

\begin{tabular}{|c|c|c|c|c|}
\hline \multirow[b]{2}{*}{ samples } & \multirow[b]{2}{*}{ reaction conditions } & \multirow[b]{2}{*}{ BET surface area $\left(\mathrm{m}^{2} / \mathrm{g}\right)$} & \multicolumn{2}{|c|}{ pore volume $(\mathrm{mL} / \mathrm{g})$} \\
\hline & & & absorption & desorption \\
\hline $\mathrm{CaSO}_{4}$ & prior to reaction & 3.02 & 0.0129 & 0.0133 \\
\hline $\mathrm{CaSO}_{4}+10 \mathrm{~mol} \% \mathrm{Ni}-\mathrm{Fe}$ mixed salts $(\mathrm{Ni} / \mathrm{Fe}=1 / 2)$ & prior to reaction & 4.86 & 0.0315 & 0.0330 \\
\hline $\mathrm{CaSO}_{4}$ & $\begin{array}{l}\text { reaction for } 120 \mathrm{~min} \\
\text { at } 800^{\circ} \mathrm{C}\end{array}$ & 4.11 & 0.0252 & 0.0264 \\
\hline $\begin{array}{l}\mathrm{CaSO}_{4}+10 \mathrm{~mol} \% \mathrm{Ni}-\mathrm{Fe} \text { mixed } \\
\text { salts }(\mathrm{Ni} / \mathrm{Fe}=1 / 2)\end{array}$ & $\begin{array}{l}\text { reaction for } 30 \mathrm{~min} \\
\text { at } 650^{\circ} \mathrm{C}\end{array}$ & 7.51 & 0.0352 & 0.0371 \\
\hline
\end{tabular}

Table 3. XRD Results of Samples with Extra Amount of Catalysts Precursors Added ${ }^{a}$

\begin{tabular}{|c|c|c|c|}
\hline $\begin{array}{l}\text { sample composition } \\
\text { (catalyst: } \mathrm{CaSO}_{4} \text { molar ratio) }\end{array}$ & catalyst precursors & reaction time $(\mathrm{min})$ & phases detected in samples \\
\hline $\begin{array}{l}1: 0 \\
1: 0 \\
1: 2 \\
1: 2 \\
1: 2 \\
1: 2 \\
1: 2 \\
1: 2\end{array}$ & $\begin{array}{l}\mathrm{Ni}\left(\mathrm{NO}_{3}\right)_{2} / \mathrm{Fe}\left(\mathrm{NO}_{3}\right)_{3} \\
\mathrm{Ni}\left(\mathrm{NO}_{3}\right)_{2} / \mathrm{Fe}\left(\mathrm{NO}_{3}\right)_{3} \\
\mathrm{Ni}\left(\mathrm{NO}_{3}\right)_{2} / \mathrm{Fe}\left(\mathrm{NO}_{3}\right)_{3} \\
\mathrm{Ni}\left(\mathrm{NO}_{3}\right)_{2} / \mathrm{Fe}\left(\mathrm{NO}_{3}\right)_{3} \\
\mathrm{Ni}\left(\mathrm{NO}_{3}\right)_{2} / \mathrm{Fe}\left(\mathrm{NO}_{3}\right)_{3} \\
\mathrm{Fe}\left(\mathrm{NO}_{3}\right)_{3} \\
\mathrm{Fe}\left(\mathrm{NO}_{3}\right)_{3} \\
\mathrm{Fe}\left(\mathrm{NO}_{3}\right)_{3}\end{array}$ & $\begin{array}{l}\text { prior to reaction } \\
60 \\
\text { prior to reaction } \\
10 \\
60 \\
\text { prior to reaction } \\
10 \\
60\end{array}$ & $\begin{array}{l}\alpha-\mathrm{Fe}_{2} \mathrm{O}_{3}, \mathrm{NiFe}_{2} \mathrm{O}_{4}, \mathrm{NiO} \\
\gamma-\mathrm{FeNi}_{2}, \mathrm{Fe}_{3} \mathrm{C}, \mathrm{FeC} \\
\mathrm{CaSO}_{4}, \alpha-\mathrm{Fe}_{2} \mathrm{O}_{3}, \mathrm{NiFe}_{2} \mathrm{O}_{4} \\
\mathrm{CaSO}_{4}, \mathrm{CaS}, \alpha-\mathrm{Fe}_{2} \mathrm{O}_{3}, \mathrm{NiFe}_{2} \mathrm{O}_{4}, \mathrm{Fe}_{3} \mathrm{O}_{4} \\
\mathrm{CaS}, \gamma-\mathrm{FeNi} \\
\mathrm{CaSO}_{4}, \alpha-\mathrm{Fe}_{2} \mathrm{O}_{3} \\
\mathrm{CaSO} \\
\mathrm{CaS}, \alpha-\mathrm{CaS}, \alpha-\mathrm{FeS} \mathrm{O}_{2} \mathrm{O}_{3}, \mathrm{Fe}_{3} \mathrm{O}_{4}, \mathrm{FeS}\end{array}$ \\
\hline
\end{tabular}

a $\left.\mathrm{T}=660{ }^{\circ} \mathrm{C}, \mathrm{CO} \%=30 \%, \mathrm{Ni} /(\mathrm{Ni}+\mathrm{Fe})=1 / 3\right)$.

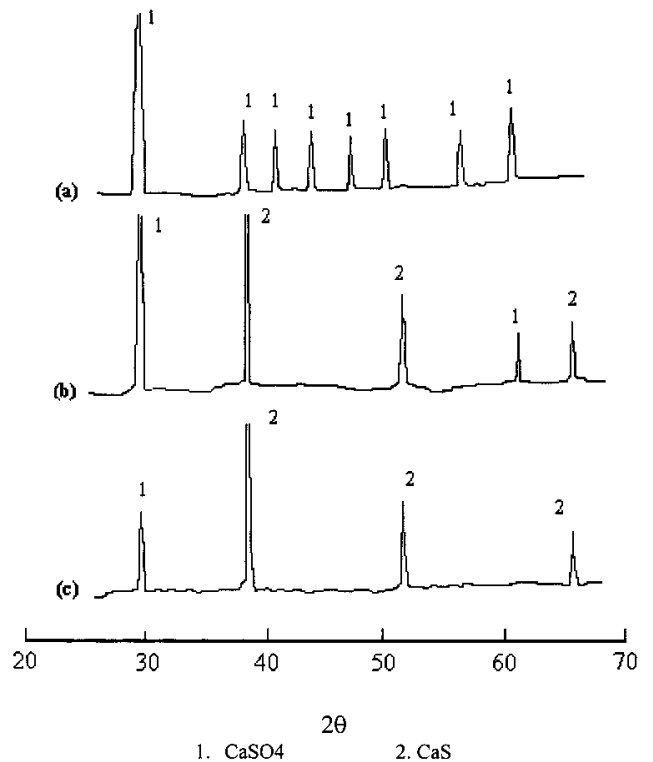

Figure 8. XRD partterns of samples after reactions. (a) Control sample with no metal salts added after reaction for $120 \mathrm{~min}$ at $750^{\circ} \mathrm{C}$. (b) Sample with $10 \mathrm{~mol} \%$ ferric nitrate added after reaction for $30 \mathrm{~min}$ at $650{ }^{\circ} \mathrm{C}$. (c) Sample with $10 \mathrm{~mol} \% \mathrm{Ni}-\mathrm{Fe}$ mixed nitrates added after reaction for $30 \mathrm{~min}$ at $650{ }^{\circ} \mathrm{C}$.

is apt to absorb the reducing gas and to react with it. Similarly, the surface structure of sample $d$ is much looser than that of sample c.

From Table 2, it is noted that the BET surface area and pore volume of reacted samples or samples with mixed catalysts added are higher than those of samples before reaction or samples without catalysts. The results are consistent to the results in Figure 7.

From Figure 8, we can see that after reduction for $120 \mathrm{~min}$ at $750{ }^{\circ} \mathrm{C}$ the predominant phase in sample a remains to be $\mathrm{CaSO}_{4}$, whereas after reduction for $30 \mathrm{~min}$ at $650{ }^{\circ} \mathrm{C}$, the predominant phase in the samples $b$ and sample $c$ is calcium sulfide. The results indicated that both catalysts can promote the reduction of calcium sulfate. Sample b still includes some unconverted calcium sulfate, whereas sample c contains only a very small amount of unreacted calcium sulfate. Consequently, $\mathrm{Ni}$-Fe mixed salt is more active than the ferric salt.
However, no diffraction peaks of added metal salts can be observed in Figure 8b,c. This might be explained by the highly dispersed status of metals in the samples or by the low concentrations of the metal salts. To study the composition of catalysts, we purposely prepared samples with extra amounts of catalysts added.

$X R D$ results in Table 3 show that phases of added metal salts present in the samples can be detected then. $\mathrm{Ni}-\mathrm{Fe}$ mixed oxides can form a chemical compound $\mathrm{NiFe}_{2} \mathrm{O}_{4}$ under the reaction conditions. The formation of $\mathrm{NiFe}_{2} \mathrm{O}_{4}$ might explain why the conversion reaches a maximum value in the case that $\mathrm{Ni} /(\mathrm{Ni}+\mathrm{Fe})=1 / 3$ (Figure 2). It is known that the addition of $\mathrm{Ni}(\mathrm{II})$, Co(II), or $\mathrm{Mn}$ (II) leads to the formation of stable ferrites $\mathrm{MFe}_{2} \mathrm{O}_{4}$ (where $\mathrm{M}=\mathrm{Mn}$, Co, or $\mathrm{Ni}$ ) with a spinel structure. ${ }^{15}$ The peak reduction temperature for $\mathrm{MFe}_{2} \mathrm{O}_{4}$ to $\mathrm{MO}-\mathrm{FeO}$ decreases in the order of $\mathrm{Co}>\mathrm{Mn}>\mathrm{Ni}$. As for the mechanism of the catalytic reduction, we postulate the following reaction cycle:

iron oxides or $\mathrm{NiFe}_{2} \mathrm{O}_{4}+\mathrm{CO} \rightarrow$

$$
\mathrm{Fe}, \mathrm{FeO} \text { or } \mathrm{NiFe}+\mathrm{CO}_{2}
$$

$$
\begin{aligned}
& \mathrm{Fe}, \mathrm{FeO} \text { or } \mathrm{NiFe}+\mathrm{CaSO}_{4} \rightarrow \\
& \text { iron oxides or } \mathrm{NiFe}_{2} \mathrm{O}_{4}+\mathrm{CaS}
\end{aligned}
$$

After all calcium sulfate has been consumed, the following reaction will take place:

$$
\text { iron oxides or } \mathrm{NiFe}_{2} \mathrm{O}_{4}+\mathrm{CO} \rightarrow \text { Fe or } \mathrm{NiFe}+\mathrm{CO}_{2}
$$

Although the proposed mechanism corresponds to the results of Table 3, it is still unclear how a solid-solid reaction can proceed rapidly and whether there are some gaseous intermediates such as metal carbonyls involved in this reaction. Further studies are needed.

\section{Conclusions}

Catalysts can effectively promote the reduction of calcium sulfate to calcium sulfide. Ferric salt is the precursor of an active catalyst, and $\mathrm{Fe}-\mathrm{Ni}$ mixed salts have the best performance among all tested catalysts. The valency of iron in the catalyst has a significant 
effect on the reduction reactions. The conversion is lower if bi- or zerovalent iron species are used as the precursor. Temperature is a key factor on the reduction reaction: conversion increases with an increase of temperature. Other factors include the composition and the concentration of catalysts, the reaction time, and the concentration of $\mathrm{CO}$. Under optimum conditions, the conversion of cal cium sulfate to cal cium sulfide is more than $95 \%$ for $30 \mathrm{~min}$ at $660^{\circ} \mathrm{C}$. SEM results show that the catalysts are highly dispersed in samples and thus can promote the reduction reactions. XRD results show that $\mathrm{Ni}-\mathrm{Fe}$ oxides can form $\mathrm{NiFe}_{2} \mathrm{O}_{4}$ under the reaction conditions, and this might explain why $\mathrm{Ni}-\mathrm{Fe}$ mixed salt is more active.

\section{Acknowledgment}

This work was supported by the Chinese Natural Science Foundation under the Project No. 29477277.

\section{Literature Cited}

(1) Harben, P. W.; Bates, R. L. Geology of the Nonmetallics; Metal Bulletin, Inc:: New York, 1984.

(2) Ellison, W.; Hammer, E. FGD-gypsum use penetrates US wall board industry. Power 1988, 132 (2), 29.

(3) Sliger, A. G. The M. W. Kellogg company Kel-S process. Proc. Int. Symp. Phosphogypsum, 2nd 1986, 2, 83.

(4) Ragin, M. M.; Brooks, D. R. Recovery of sulfur from phosphogypsum. Part 1. Conversion of calcium sulfate to calcium sulfide. Proc. Int. Symp. Phosphogypsum, 2nd 1986, 2, 117.

(5) Rice, D. A.; Carter, O. C.; Alexander, J . M.; Ragin, M. M.; Swanton, R. G. Recovery of sulfur from phosphogypsum: Conversion of calcum sulfide to sulfur. RI 9297; Bur. Mines Rep. Invest. 1990.
(6) Zhuang, Y. H.; Li, H. J . A process of reduction FGD waste, phosphogypsum or natural gypsum. Chinese Patent 98101761.4, 1998.

(7) Biswas, S. C.; Sabharwal, V. P.; Dutta, B. K. Sulfur from gypsum: Reduction of gypsum to calcium sulfide. Technol ogy 1971 8 (1), 52.

(8) Smith, J . C.; Reinhardt, J . R. Increasing the rate of reaction in reducing calcium sulfate to calcium sulfide. U.S. Patent 3,640,682, 1972.

(9) J ha, A.; Grieveson, P. Calcination of calcium sulphate in the presence of carbon and calcium sulphide. Scand. J . Metall. 1990, 19, 39.

(10) Kale, B. B.; Pande, A. R.; Gokarn, A. N. Studies in the carbothermic reduction of phosphogypsum. Metall. Trans. B 1992, 23B, 567.

(11) Ragin, M. M.; Brooks, D. R. Recovery of sulfur from phosphogypsum: Conversion of calcium sulfate to calcium sulfide. RI 9323; Bur. Mines Rep. Invest. 1990.

(12) Trikkel, A.; Kuusik, R. Tallinna Tehnikaulik. Toim. 1994, $742,45$.

(13) Zadick, T. W.; Zavaleta, R.; McCandless, F. P. Catalytic reduction of calcium sulfate to calcium sulfide with carbon monoxide. Ind. Eng. Chem. Proc. Des. Dev. 1972, 11, 283.

(14) Turkdogan, E. T. The Physical Chemistry of High-Temperature Technology; Academic Press: London, 1980.

(15) Zhang, C. L.; Li, S.; Wang, L. J .; Wu, T. H. Temperature programmed reduction of ferrites. Chin. J . Chem. Phys. 1999, 12 (2), 244.

Received for review March 2, 1999 Revised manuscript received J une 9, 1999 Accepted J une 9, 1999

IE 9901628 